\section{A model to assess the relationship between management opportunism and auditor reaction. Simulation on financial restatements and on a sample of Brazilian companies listed on NYSE}

\author{
Adela Deaconu ${ }^{1}$ \\ Camelia-Daniela Hategan ${ }^{2}$ \\ Ioana Ciurdas ${ }^{1}$
}

Received on:

09/12/2019

Approved on:

06/23/2020

\section{Responsible Editor: \\ Prof. Dr. Ilidio Lopes}

\section{Evaluation process:}

Double Blind Review

\section{Reviewers:}

Both reviewers decided not to disclose their identities.

\title{
Abstract
}

Purpose - The objective of the paper is to investigate whether managers behave opportunistically by manipulating earnings and whether financial restatements, required by the auditors from the auditees, have the potential to decrease management opportunism.

Design/methodology/approach - The empirical approach undertaken uses a self-constructed model in order to detect the influence of financial restatements on discretionary accruals and to observe possible earnings management practices, considering financial restatements as the explanatory variable.

Findings - The values computed for discretionary accruals confirm the existence of earnings management and suggest possible management bias in accounting estimates and other accounting policies.

Originality/value - This study provides a tool for overcoming deficiencies in relation to accounting estimates and other accounting policies in the auditing process, by assessing the relationship between management opportunism and auditors' reactions using financial restatement requirements.

Keywords - accounting estimates, financial restatements, audit risk, earnings management, discretionary accruals.

1. Babes-Bolyai University, Accounting and Audit Department, Cluj-Napoca, Romania

2. West University of Timisoara, Accounting and Audit Department, Timisoara, Romania

How to cite:

Deaconu, A., Hategan, C., Ciurdas, I. (2021) A model to assess the relationship between management opportunism and auditor reactions. Simulation on financial restatements for a sample of Brazilian companies listed on the NYSE. Revista Brasileira de Gestão de Negócios, 23(1), firstpage-lastpage.

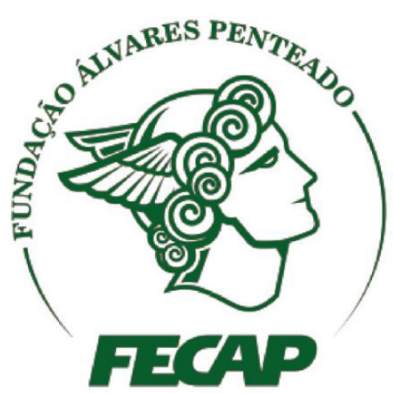

Revista Brasileira de Gestão de Negócios

https://doi.org/10.7819/rbgn.v23i2.4101 


\section{Introduction}

In light of the many well-known financial scandals that have occurred, it is highly recommended for the users of accounting information to be able to evaluate financial reporting quality (FRQ hereinafter) and to filter related effects in order to understand the reported figures (Beneish, Press, \& Vargus, 2012; Zang, 2012). The International Accounting Standards Board (IASB) documents (2012) highlight the need for corporate financial statements to provide a high level of relevance - one of the two fundamental qualitative characteristics of financial information in order for it to be useful.

It is therefore important to understand the extent to which accounting estimates and other disclosures (for example, the classification of elements in financial statements and the capitalization of expenditures), as well as elements of accounting reasoning and management discretion, can affect the information disclosed. These effects are not only relevant for the users of financial statements, but also for auditors. Users are concerned about FRQ, particularly earnings quality. Auditors are aware of the difficulty of auditing accounting estimates and other elements of the accounting professional's reasoning (hereinafter referred to, for convenience, as estimates), which affect the accuracy of the information disclosed by their clients. In addition, auditors provide FRQ guarantees for users.

Company management can willingly or unwillingly influence estimates in accounting. Recent literature has emphasized the need to identify explicit indicators of management bias in judgments related to estimates (Abernathy, Hackenbrack, Joe, Pevzner, \& Wu, 2015). In response to such concerns, analysts have developed tools for pinpointing the risks faced by the users of accounting information and the elements to be taken into consideration when comparing between financial years. Audit Analytics (AA), a database dedicated to financial information and auditing (AA, 2018), provides a matrix for assessing accounting quality and risks (AQRM), covering financial reporting, internal controls, stakeholders, and auditors. Among other things, AA intends to highlight indicators of potential earnings management.

Our paper focuses on financial restatements (restatements hereinafter) as corrections of material misstatements observed in previously issued financial statements. In our view, restatements are a possible consequence of the way estimates are provided by audited companies and one of the financial reporting red flags for risk. They are also representative of FRQ and potential management opportunism or bias (Ettredge, Scholz, Smith, \& Sun, 2010). The data were collected from the AA database, as restatements are one of the items pertaining to financial reporting in the AQRM matrix, and are relevant to achieving our objective.

We also focus on the perceptions of the auditors in charge, who must provide reasonable assurance for the financial statements of a company. Potentially biased estimates, due to subjective assessments and reasoning, are a real burden for the auditors who have to deal with them. Glover, Taylor, and Wu (2014) highlighted the need for more clarity and guidance for auditors regarding estimates in general, and fair value measurements in particular. The audit risk associated with estimates and the effects on auditors' decisions are at the core of several recent studies (e.g. Bratten, Gaynor, McDaniel, Montague, \& Sierra, 2013; Christensen, Glover, \& Wood, 2012; Griffin, 2014). At a regulatory level, the Public Company Accounting Oversight Board (PCAOB) (2014) launched an invitation for public comments on its Staff Consultation Paper 'Auditing Accounting Estimates and Fair Value Measurement,' in response to the need to update audit standards for accounting estimates. This proposal was submitted for approval to the Securities and Exchange Commission in 2019.

Our intention is to analyze the relationship between restatements and management bias, the latter of which is expressed by earnings management tactics. Although the literature is rich in studies related to restatements and their relationship with audit quality and/or FRQ (see DeFond \& Zhang, 2014 for a review), papers on the correlation between restatements and earnings management are scarce. Hence, our study is an attempt to enrich this specific area of literature by pursuing the following objective: to find some of the red flags or indicators that are useful to auditors for minimizing their audit risks linked to accounting estimates, re-classifications, capitalizations/ decapitalizations, and other accounting options and policies - all issues that are affected by management discretion. These issues, especially accounting estimates, cause greater measurement uncertainty and, hence, higher risks for the audit mission. Financial restatements are supposed to remediate such errors in financial statements. Based on this, we try to demonstrate if financial restatements and management discretion (measured by earnings management tactics) are correlated and, moreover, depend on each other. Therefore, our main research question is the following: 
A model to assess the relationship between management opportunism and auditor reactions. Simulation on financial restatements for a sample of Brazilian companies listed on the NYSE

when auditors have requested in the previous year for managers to restate their financial statements, are those managers less willing to resort to earnings management practices?

Furthermore, there are environments where business conditions can increase management pressure to achieve a certain level of financial performance and, as a result, there is a higher possibility of management estimates being biased (PCAOB, 2011). This is also the case of emerging markets. Therefore, our subject of inquiry is the Brazilian audit context and the Brazilian companies listed on the US market (New York Stock Exchange - NYSE). Other reasons for this choice include (1) Brazil's place among the 10 Big Emerging Markets (we intended to form as consistent a sample as possible, considering that restatements are relatively rare events); (2) our intention to explore the behavior of companies belonging to an emerging country for which earnings management has not been sufficiently revealed; and (3) the availability of data to test our model (provided by the AA database).

Therefore, as main contributions of our research, we examine whether managers manipulate earnings (shown by one measure of earnings management, i.e. discretionary accruals, in a regression model we designed). In order to enable auditors to minimize the risk associated with accounting estimates and similar issues, we provide empirically tested indicators that could suggest management opportunism (discretionary accruals), revealing its direct relationship with restatements required in previous years. As a secondary contribution, we observe the correlation between this measure of earnings management and auditee-related features, such as company size, quality of corporate governance, and investing and financing policies.

To achieve our goal, Section 2 provides a review of the literature; section 3 presents the model to be applied and the construction of the sample; section 4 provides comments on the empirical results obtained; and the final section presents the concluding remarks.

\section{Literature Review}

The theoretical basis for our research is the concept of FRQ. In the literature, the topic has been approached from an accounting theory and normalization perspective (e.g. Demsey, 1989; Nobes \& Parker, 2006), from a conceptual point of view (e.g. Lillrank, 2003), and based on the effects of financial reporting on users' decision usefulness (Staubus, 2000). Based on Staubus' (2000) theory of the decision usefulness of accounting, we analyzed papers that measure the extent to which the quality of published accounting information influences users' decisions (e.g. Barron \& Stuerke, 1998; Lee \& Masulis, 2009).

Our study is exploratory and observed how the interests of managers in financial reporting and those of the auditors who verify that information are manifested. It combines items related to (1) accounting estimates and audit risk, (2) earnings management, and (3) the link between restatements and earnings management. Therefore, we reviewed three groups of studies.

The first literature group relates to the uncertainty of the estimates as an audit risk likely to influence the auditor's decisions on potential adjustments (restatements) of financial statements. In this respect, Bratten et al. (2013) identify the uncertainty of estimates as an environmental factor that may have an impact on the measurement of estimates. The research of Griffin (2014) provides empirical evidence about how auditors make decisions related to fair value and other uncertainty in measuring. The author asserts that auditors are most likely to require auditees to adjust their estimates when both subjectivity and imprecision are high. A lack of objective data is linked to a high degree of uncertainty in some estimates. Due to the high uncertainty in reported estimates, management can be tempted to show bias (Christensen et al., 2012). This complicates the process of reducing audit risk and influences the level of materiality. Under such circumstances, the burden for auditors increases and this is why many studies (e.g. Abernathy et al., 2015; Christensen et al., 2012) suggest potential revisions of the auditing standards, in order to clarify the auditor's responsibilities with respect to estimates that contain extreme measurement uncertainty. For example, Christensen et al. (2012) recommend that the audit report should include a list of the accounts with extreme measurement uncertainty. This has been achieved through International Standard on Auditing (ISA) 700 (Revised), Forming an Opinion and Reporting on Financial Statements after December 15, 2016, issued by the International Federation of Accountants (IFAC, 2015), through the insertion of the key audit matters (KAM) paragraph in the auditor's report. However, most papers and the standards fail to provide concrete solutions to assist the auditors, only pointing out the auditor's need to verify estimates and the associated risks. 
In short, this first group of research highlights the need for auditors to be aware of management opportunistic behavior, which causes audit risks due to issues of professional accounting reasoning, for example, accounting estimates. It is therefore useful to build our main research question: do financial restatements required by auditors from auditees have the potential to reduce management opportunism?

The second literature review group relates to discretionary (abnormal) accruals (accruals anomaly), as a measure used to reveal earnings management practices. The concept has been intensively discussed in the literature in terms of its content, formulas, and applications (Filip, Huang, \& Lui, 2016; Prather-Kinsey \& Waller Shelton, 2005; Tsipouridou \& Spathis, 2014). In short, discretionary accruals represent the residual part from abnormal accruals models (e.g. Jones, 1991). Previous literature (Chan, Jegadeesh, \& Sougiannis, 2004; Dechow \& Dichev, 2002; Filip and Raffournier, 2014; Kothari, Sabino, \& Zach, 2005; Srinidhi \& Gul, 2007) has used discretionary accruals as a proxy for managers' opportunistic behavior, as they represent distortions that lower quality. The aim of computing accruals is to capture the correlation between the accruals dimension and the measures of abnormal accruals. Hence, extreme accruals imply extreme abnormal accruals (Dechow et al., 2010). Of the alternative methods of detecting discretionary accruals, we analyzed the modified Jones model developed by Dechow, Sloan, and Sweeney (1995). One of our arguments for this choice is its suitability for cross-sectional testing, by industry and year (Li, Niu, Zhang, \& Largay, 2011; Xie, 2001), which is consistent with our sample design. This choice takes it into account that, compared to firm specific (time-series) regressions, this model may generate larger residuals and have less restrictive data requirements (Mureșan, 2014). The initial Jones (1991) model considers accruals to be a function of revenue growth and depreciation of property, plant, and equipment. The residuals are correlated with accruals, earnings, and cash flow. The Jones model modified by Dechow et al. (1995) excludes growth in credit sales in the manipulation years. The model relies on the relationship between the variation in credit sales and earnings management. In the model design, abnormal accruals are the residuals and normal accruals are the difference between total and abnormal accruals. Aside from some weaknesses, our choice was ultimately based on the popularity of the Jones model, which is considered as having higher explanatory power in detecting earnings management than other models (Chan et al., 2004). The modified Jones model has even greater power of detection, according to its creators.

The findings of this second group of papers are relevant for our study since we intend to determine if managers are engaging in earnings management practices, which is our subsidiary research question. It is useful to check for the existence of earnings management in the Brazilian context, since at an international level the phenomenon may vary from context to context as a result of different accruals measures and different accounting systems (Mureșan \& Silaghi, 2014). As evidence for our study, we analyzed the research of Beckmann, Escobari, and Ngo (2019), which examined the existence of earnings management around the time of cross-listings on foreign markets, in a sample of 1349 companies listed in the US, which included 56 companies from Brazil. The results of the study indicated that companies are actively managing their earnings around cross-listing events using both real and accruals-based earnings management.

Connecting the two groups of papers, in this study we investigate whether managers manipulate earnings, speculating on the uncertainty specific to estimates, and whether restatements affect the extent of future earnings management. Therefore, the third literature review group motivates the choice of restatements as the explanatory variable in our analysis. Several authors (e.g. Larcker \& Richardson, 2004; Reynolds \& Francis, 2000) have used accounting accruals and restatements as proxies for audit quality and FRQ. Restatements are viewed by DeFond (2010) as a direct proxy for poor earnings quality. DeFond and Zhang (2014) produced a valuable review of the research on such items from the perspective of audit quality and FRQ. Also, Sievers and Sofilkanitsch's (2018) working paper offers a literature survey on the causes and effects of restatements. Nonetheless, we are aware of few studies that have directly addressed the link between restatements and earnings management. We can cite Ettredge et al. (2010), who examined the variables that may influence the use of restatements. The authors found evidence of increasing use of earnings management prior to restatements. In the Brazilian context, the objectives of the study of Cunha et al. (2017) are closer to our own. Using a discretionary accruals model, the research investigates the link between restatements and earnings management using pair samples of local listed companies that resorted or not to restatements. 
A model to assess the relationship between management opportunism and auditor reactions. Simulation on financial restatements for a sample of Brazilian companies listed on the NYSE

Overall, our study could be viewed as an exploratory one that uses a self-constructed model to link earnings management (measured by discretionary accruals) as a dependent variable to restatements as its explanatory variable, alongside other control variables that can give a specific direction to earnings management.

Usually, restatements are initiated by auditors who discover misstatements in financial statements during the audit mission. Auditors, company managers, and audit committees evaluate the nature and materiality of misstatements and make decisions considering the materiality of the errors in order to waive or make corrections to the financial statements. Then, a restatement announcement is made and the previously issued financial statements are amended for the periods affected (Big $R$ restatements). AA, the database we used, containing data for the companies listed in the US capital market, explains that restatements are errors caused by the unintentional misapplication of the accounting standards. For a better understanding, there are also little $r$ restatements that occur when a company's immaterial errors add up to a material error in a given year. Unlike Big $R$ restatements, which must be reported through a SEC 8-K material event filing, little $r$ restatements do not require an $8-\mathrm{K}$ form or withdrawal of the auditor's opinion (Tan \& Young, 2014).

To conclude this section, the research questions expressed above lead to the following research hypotheses: (1) in the Brazilian setting, managers manipulate earnings, due to the subjectivity involved in compiling estimations (in the sense previously described) ; and (2) auditors' requirements for restatements lead to a reduction in management bias, which is materialized in less earnings management.

\section{Research Design}

\section{I The model}

The model we propose aims to detect the existence of management opportunism and then verify whether the restatements requested by auditors are correlated with earnings management techniques and if they can discourage earnings management in the years following them. We chose discretionary accruals as our measure for earnings management.

We used the modified Jones model to detect the existence of discretionary accruals and hence management opportunism or earnings management techniques. Then, to observe the auditor action of requesting restatements (concerning material accounting misstatements that they could detect), we regressed this item for the earnings management measure using a multivariate model. Besides using the earnings management measure as a dependent variable and restatements as an explanatory (independent) variable, we judged it appropriate to use control variables that could affect the direction of earnings management. These control variables are related to the auditee's (audited company) characteristics. Our final multivariate model is adapted from the work of Vander Bauwhede, Willekens, and Gaeremynck (2003), as follows:

DACit $+1=\beta 0+\beta 1 x$ RESTit $+\beta 2 x$ RESTCSit $+\beta 3$ CSit + $\beta 4 x$ GOVit $+1+\beta 5 x$ LEVit $+1+\beta 6$ xINVTANit $+1+\varepsilon$

Where:

DAC - discretionary accruals computed as residuals REST - restatement of the financial statements requested by the auditor due to material misstatements

RESTCS - interaction variable between REST and CS CS - company size

GOV - corporate governance quality of the audited company

LEV - leverage ratio

INVTAN - net investments in tangible assets

The DAC value indicates the existence of discretionary accruals, more precisely the presence of earnings management techniques. In order to estimate DAC we looked at the residuals in the equation, where total accruals (Acc) are calculated in two ways (1 and 2 in Table 1). We ran the regression and then predicted the estimated error term $(\varepsilon)$, which is equal to discretionary accruals.

The main explanatory (independent) variable for the auditor's actions intended to counteract management opportunistic behavior suggested by DAC is REST (restatements). There are two categories of REST: qualitative and technical. Qualitative restatements amend financial statements and the disclosed effect is viewed in net income, earnings per share, and shareholders' equity. Technical restatements do not imply quantitative effects but modifications of accounting policies, corrections of misclassifications, or corrections of certain errors. REST is presented in $\mathrm{AA}$ as a positive or negative effect on cumulative change in net income and cumulative change in stockholder equity for the qualitative restatements type, along with the value. For technical restatements, only the 
Table 1

\section{Specification of the model variables}

\begin{tabular}{|c|c|c|}
\hline Variables & Analysis elements within the variables & Type of variable \\
\hline \multicolumn{3}{|c|}{ Independent variables } \\
\hline $\begin{array}{l}\text { REST - financial restatements requested } \\
\text { by the auditor due to misstatements in the } \\
\text { financial statements }\end{array}$ & $\begin{array}{c}1 \text { if the company produced a restatement in } \\
\text { year T; } 0 \text { otherwise }\end{array}$ & Dummy \\
\hline CS - company size & $\begin{array}{l}\text { Measured as the natural logarithm of the } \\
\text { company's total assets }\end{array}$ & Continuous \\
\hline RESTCS & $\begin{array}{c}\text { Interaction variable between REST and } \\
\text { Company size }\end{array}$ & Continuous \\
\hline $\begin{array}{l}\mathrm{GOV}^{*} \text { - corporate governance strength } \\
\text { for the audited company measured by the } \\
\text { Disclosure control variable, } \\
\text { SOX } 302\end{array}$ & $\begin{array}{c}1 \text { if the company reported material weakness } \\
\text { for the internal control, under SOX 302; } 0 \\
\text { otherwise }\end{array}$ & Dummy \\
\hline LEV - leverage ratio for the auditee* & Ratio of debt over total assets & Continuous \\
\hline $\begin{array}{l}\text { INVTAN - net investments in tangible } \\
\text { assets for the auditee* }\end{array}$ & $\begin{array}{c}\text { Changes in tangible assets from the previous } \\
\text { year, scaled by lagged total assets }\end{array}$ & Continuous \\
\hline AUDIT $\operatorname{rot}^{*}, * *$ - auditor rotation & $\begin{array}{l}1 \text { if the company had a new/another } \\
\text { auditor; } 0 \text { otherwise }\end{array}$ & Dummy \\
\hline \multicolumn{3}{|c|}{ Dependent variable } \\
\hline $\begin{array}{c}\text { DAC - discretionary accruals computed as } \\
\text { residuals }(\varepsilon)^{*}\end{array}$ & $\begin{array}{c}\text { Acc }=\alpha+\beta 1(\triangle \mathrm{REV}-\triangle \mathrm{REC})+\beta 2 \mathrm{PPE}+\varepsilon(1) \\
\text { All variables are deflated by lagged total } \\
\text { assets. } \\
\mathrm{REV}-\text { change in sales revenue } \\
\mathrm{REC}-\text { change in accounts receivable } \\
\mathrm{PPE}-\text { property, plant, equipment } \\
\text { Acc }- \text { total accruals } \\
\text { Acc }=\text { net income }- \text { cash flow from } \\
\text { operations }(2)\end{array}$ & Continuous \\
\hline
\end{tabular}

Note. ${ }^{\star}$ Variable’s value in $\mathrm{T}+1 ;{ }^{*}$ Used only for the robustness test

positive or negative effects, without the value, are reported. Due to these four different categories and the lack of values reported for all the categories, we ultimately used the dummy variables for REST, noting if the restatements were required or not for a certain company-year.

We introduced company size (CS) as a variable in the model based on its effect on DAC, as argued in several studies (Cassell, Myers, Myers, \& Seidel, 2014; Myers, Myers, \& Omer, 2003; Watts \& Zimmerman, 1990). Then, we created a variable for the interaction between restatements and company size to control if the effect of restatements on DAC depends on another variable.

The other independent variables are control variables indicating economic factors specific to the auditee (company-related), which are potential influencers of DAC.

Specific literature provides estimators for the quality (strength) of corporate governance (GOV) that inspire our model. In their study conducted on Spanish companies included in the Ibex 35 stock price index, TejedoRomero, Araujo, and Emmendoerfer (2017) conclude that the disclosure of financial information is influenced by good governance, which is analyzed by estimators such as ownership structure, board of directors, separation of the chief executive officer (CEO) and chairman roles, and board size. In their study regarding the impact of accounting standards precision (misreporting risk) on restatements, Fang, Pittman, Zhang, and Zhao (2018) used CEO equity incentives, board independence, and audit committee independence as indicators of corporate governance. Other mechanisms of corporate governance used by some researchers are indicated in sections 302 and 404 of the Sarbanes Oxley Act (SOX), which requires management to report any material weakness in their internal controls over financial reporting (Chen, Elder, \& Hung 2014; Hirschey, Smith, \& Wilson, 2010). Particularly relevant to the Brazilian market is the study of Marques, Sousa, Amaral, and Santos (2017), which uses the "differentiated levels of governance" of companies whose shares are traded on the BM\&FBOVESPA as a measure of the level of corporate governance, specifically 
A model to assess the relationship between management opportunism and auditor reactions. Simulation on financial restatements for a sample of Brazilian companies listed on the NYSE

the application of SOX, in relation to restatements. In our model, we consider as an estimator of corporate governance quality whether the company reported an internal control material weakness under SOX section 302 (SOX 302 was operational after 2002).

Another two control variables of our model are leverage ratio as a measure of company performance and net investments in tangible assets as a measure of investments. Vander Bauwhede et al. (2003) used these variables to control for any potential measurement errors in DAC, taking into account that the model used for the DAC calculation (which is similar to ours) does not allow for changes in total accruals due to changes in the company's economic condition. In addition, we believe that leverage can influence management behavior when deciding whether to resort to earnings management practices, as argued by a substantial amount of literature (e.g. Jones \& Sharma, 2001; Shah, 1998). Leverage was also connected to the probability of the company having to produce restatements (Tan \& Young, 2014). We also view investments in tangible assets as a reference correlated to financial soundness of the company, expecting a negative influence on DAC. We computed the leverage ratio as the weight of debts in total company assets, similar to in other studies (Ardison, Martinez, \& Galdi, 2012; Dichev $\&$ Skinner, 2002). The composition of the investments in tangible assets variable is similar to the one indicated by Vander Bauwhede et al. (2003), but it was adapted to our data. The calculation was made using balance sheet data, as the variation in tangible assets in consecutive years.

Our model assumes that signs of earnings management cause a requirement for restatements, and that these restatements affect management behavior in the future. Aware of the reversibility of the relationship between restatements and earnings management ((a) restatements affecting earnings management, as well as (b) earnings management affecting restatements), we clarified in Figure 1 that only relationship (a) would be tested. Also, to counteract the effect of the endogeneity, we shifted the values of the variables in time, similar to in other studies (e.g. Feldmann, 2010). Thus, the variables REST, CS, and RESTCS have values for year T and DAC and its control variables have values for year $T+1$.

Table 1 describes the measurement of the dependent and independent variables.

\subsection{The sample}

We chose Brazil as the setting of our inquiry firstly because we were looking for a large emerging country for which our specific data, especially restatements, are available. As summary statistics, the economy of Brazil was the world's ninth-largest by nominal gross domestic product in 2018 and also, as a member of the BRICS group, Brazil had one of the world's fastest growing major economies until 2010 (IMF, 2018, https://www.imf.org/ en/Countries/BRA). This is also the year when Brazilian listed companies adopted IFRS (Consoni \& Colauto, 2016). The size and economic advancement of the country suggested a greater likelihood of finding listed companies in the AA database and the reporting of restatements.

Secondly, Brazil is a context that is less explored in terms of discretionary accruals. The available research targets mostly the US (e.g. Leippold \& Lohre, 2012; Sloan, 1996; Xie, 2001) and then the UK (Chan, Chan, Jegadeesh, \& Lakonishok, 2006), Spain (Goncharov, Hodgson, Lhaopadchan, \& Sanabria, 2013), China

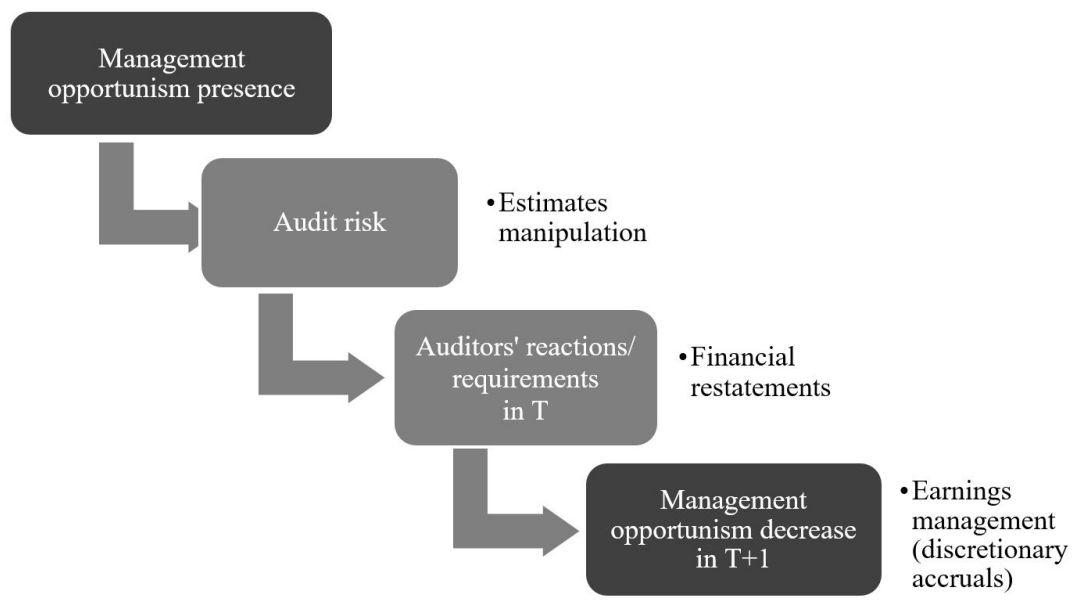

Figure 1. Model logic 
(Li et al. 2011), or Tunisia (Mehdi, 2011). Pincus, Rajgopal, and Venkatachalam (2007) and Leippold and Lohre (2012) also claim that such evidence outside the US is scarce and presents conflicting results. We selected Brazilian companies listed in the US capital market also due to the availability of data.

Our analysis targets the period 2000-2016, which covers the years for which the information on restatements made by the Brazilian companies is available in the AA database. AA contains a database related to accounting, audit, and risk intelligence and provides insights into financial situations, auditor and management reports, corporate governance, and other features conceived in our model. In addition to the AA database, we used the financial information provided by the Thomson Reuters Eikon database.

Our sample contains 425 observations (from 25 companies), including, for each company, the years for which accounting misstatement corrections were made, as well the years without restatements. To obtain this, we selected those years for which at least one company amended the financial statements issued through restatements, for at least one year, In AA we observed a total of 77 listed companies, from which we selected only the ones whose reasons for restatement problems related to the accounting estimates. We obtained a total of 35 companies which met these first criteria. From this initial sample, we have eliminated the companies in the financial services industries and those with missing information for all control variables for all years. We also excluded three companies for being part of the same group that was already included in the sample, resulting in 97 restatements for the 2000-2016 period from 25 different companies. For the continuous variables, the data were reported in AA in US dollars (USD) or in Brazilian reals and we converted the amounts into USD at the exchange rate reported at the end of each financial period. Tan and Young (2015) reported that in the past few years many companies have not announced restatements in the specific form required by SEC (Form 8-K) and have avoided amending their financial statements, revising only the affected numbers for the previous periods in subsequent quarterly or annual reports (little $r$ restatements). This could be an explanation for the decline in the number of restatements in the second period of analysis (in our database there are 59 observations of the REST variable in 2000-2010 and 38 in 2011-2016, representing a decrease of $36 \%$ ). Another supposition is the application of IFRS from 2010, which could have increased the quality of the financial information and prevented the requirements for restatements. The final database is an unbalanced panel, since we lack information for some variables, for certain years. The REST cases in our sample account for different issues, the majority being related to estimates and others being mainly associated with re-classifications. Our statistics on the hierarchy of the most common reporting issues for the Brazilian sample indicate for the first three positions items such as (1) cash flow statement classification errors; (2) debt and/or equity classification issues or Debt, quasi-debt, warrants, and equity security issues; and (3) expense recording issues, respectively.

\section{Analysis and Results}

In addition to the preliminary and robustness tests, we used two other sets of tests, the first designed to present the characteristics and homogeneity/dissimilarity of each type of variable and the second focusing on possible significant correlations between variables.

\section{I Preliminary tests}

As a preliminary test, we verified our continuous data for unit roots, applying the Fisher test (Choi, 2001), and the option of D. Fuller and P. Perron, which is appropriate for unbalanced panels. The results of the test (see Table 2, which displays the results without lags and with one lag) suggest that the data are stationary and that unit roots do not exist.

Table 2

\section{Stationarity analysis}

\begin{tabular}{|c|c|c|c|}
\hline \multirow{3}{*}{$\begin{array}{c}\text { Test/ Variable } \\
\text { Fisher } \\
\text { (no lags) }\end{array}$} & \multicolumn{2}{|c|}{ D. Fuller } & \multirow{3}{*}{$\begin{array}{c}\text { P. Perron } \\
\text { Time trend } \\
p \text {-value }\end{array}$} \\
\hline & Time trend & Drift term & \\
\hline & p-value & p-value & \\
\hline $\mathrm{DAC}$ & 0.000 & 0.000 & 0.000 \\
\hline LEV & 0.000 & 0.000 & 0.000 \\
\hline INVTAN & 0.000 & 0.000 & 0.000 \\
\hline CS & 0.002 & 0.000 & 0.002 \\
\hline \multicolumn{4}{|l|}{$\begin{array}{l}\text { Fisher } \\
\text { (one lag) }\end{array}$} \\
\hline DAC & 0.002 & 0.000 & 0.000 \\
\hline LEV & 0.000 & 0.057 & 0.000 \\
\hline INVTAN & 0.000 & 0.000 & 0.000 \\
\hline CS & 0.143 & 0.000 & 0.001 \\
\hline
\end{tabular}

Note. ${ }^{\star}$ Fisher-type tests have as the null hypothesis that all the panels contain a unit root 
A model to assess the relationship between management opportunism and auditor reactions. Simulation on financial restatements for a sample of Brazilian companies listed on the NYSE

Table 3

Frequencies for the independent dummy variables

\begin{tabular}{|c|c|c|c|c|c|}
\hline Variable $(n=425)$ & Freaun (0/) & Variable $(n=290)$ & Freaun (0/) & Variable $(n=308)$ & Freanencr (0\%) \\
\hline REST & Frequency (\%) & GOV & Frequency (\%) & AUDIT_rot & Frequency (\%) \\
\hline 0 & 77.18 & 0 & 85.86 & 0 & 81.49 \\
\hline 1 & 22.82 & 1 & 14.14 & 1 & 18.51 \\
\hline
\end{tabular}

Note. REST = restatements required (1 for occurrence of the event); GOV = quality if the internal control/corporate governance; AUDITOR_rot $=$ auditor change from one year to another.

Table 4

Descriptive statistics for continuous variables $(n=311,322$, and 349 , respectively)

\begin{tabular}{ccccc}
\hline Variable & Minimum & Maximum & Mean & Std. Deviation \\
\hline DAC & -3.4165 & 0.4469 & -0.0004 & 0.2332 \\
LEV & 0.0422 & 2.4519 & 0.6457 & 0.2088 \\
INVTAN & -0.6959 & 2.5876 & 0.0820 & 0.2849 \\
\hline
\end{tabular}

Note. DAC = discretionary accruals, INVTAN = changes in tangible assets from the previous year, LEV = leverage ratio

\subsection{Descriptive Statistics}

Table 3 shows the data for our independent variables expressed by dummy values, namely REST, as one of the main explanatory variables for the management behavior suggested by DAC, and for some of the control variables.

The frequency of the cases of weak internal control is six times lower than for the rest of the sample, suggesting a relatively good quality of corporate governance overall. The ratio of cases of changes of auditor compared to stability of this role is 1 to 4 .

Table 4 shows descriptive statistics for our continuous variables, namely DAC, as the dependent variable, and INVTAN and LEV as control variables.

LEV and INVTAN have a similar and low standard deviation, denoting relative homogeneity of the companies in financing and investment decisions. Table 4 and the DAC values disclosed in our database reveal the presence of earnings management techniques. We can consider earnings manipulation to be present since abnormal accruals were under the values of the error term, either negative or positive, and hence different from 0 . Therefore, the accounting figures have been manipulated (up or down), depending on the management aim, according to our first research hypothesis.

Furthermore, for the metrics expressed by dummy values, we examined whether the means were not significantly different, indicating that the variation in the proxies was constant (Table 5). The test was performed between the dependent variable DAC and these variables.

Homogeneity can be observed throughout the entire 2000-2016 period ( $p>0.05)$, for all the variables above, especially for REST and GOV, suggesting that the
Table 5

ANOVA test between DAC and dummy variables

\begin{tabular}{cccc}
\hline Tests & REST & GOV & $\begin{array}{c}\text { AUDITOR_ } \\
\text { rot }\end{array}$ \\
\hline F & 0.430 & 0.0060 & 3.030 \\
p-Value & 0.514 & 0.800 & 0.083 \\
\hline
\end{tabular}

Note. REST $=$ restatements, GOV $=$ quality if the internal control/corporate governance, AUDITOR_rot $=$ auditor change from one year to another

Table 6

\section{Pearson correlation results among continu- ous variables}

\begin{tabular}{cccc}
\hline & DAC & LEV & INVTAN \\
\hline DAC & 1 & $-0.5476^{* *}$ & 0.0199 \\
LEV & & 1 & -0.0698 \\
INVTAN & & & 1 \\
\hline
\end{tabular}

Note. ${ }^{*}$ Correlation is significant at the 0.01 level (2-tailed). DAC $=$ discretionary accruals, INVTAN = changes in tangible assets from the previous year, LEV = leverage ratio

statistical hypothesis regarding equal means is confirmed. This result indicates that there is a constant evolution of these influential factors of DAC. We did not obtain the same results for the AUDIT_rot variable, which will be used for the robustness tests and not for the main model.

Pearson correlation coefficients were used to examine the relationship between the continuous dependent and the independent variables (Table 6).

Considering statistical significance for $p<0.01$, there is no correlation between INVTAN and LEV as independent variables, suggesting that the regression 
analysis can be performed. Also, there is an important link between DAC as a dependent variable and LEV, a first sign of this variable's significance for the model.

\subsection{Regression analysis}

We performed a pooled OLS regression on our panel data, with DAC as a dependent variable and REST (and RESTCS) as main independent variables. The analysis was conducted on two sets of independent variables, namely the explanatory (REST and RESTCS) and the control variables (company-related).

After testing, the model obtained $\mathrm{R}^{2}=0.4795$ and $\mathrm{R}^{2} \mathrm{Adj} .=0.4670$. The synthetic results for the representativeness of the model are presented in Table 7.

For the levels of statistical significance indicated, Table 7 shows a negative correlation between REST and the presence of the earnings management phenomenon suggested by DAC in the following year. Overall, for all the companies and years, it seems that restatements in one year lead to a decrease in manager opportunistic behavior in the following year. Also, the standardized beta coefficients indicate that the larger the company is, the greater the effect is of restatements on DAC. This could suggest that the decision to issue restatements tempers management opportunism. Therefore, our second research hypothesis is validated.

These results are consistent with those of other studies on the correlation between restatements and earnings management. There are, however, some differences between these and our study regarding the nuances of this relationship. Ettredge et al. (2010) test the association between balance sheet bloat (cumulative effect of earnings management on the balance sheet) and misstatement types (restatements qualified as fraud, due to intentional manipulation by management or due to simple errors). They observed that earnings are managed upwards as long as there is sufficient leeway in balance sheet accounts to permit income-increasing accounting choices. Elshafie and Nyadroh's (2014) results show a significant and positive association between discretionary accruals and audit quality measured by the likelihood of restatements of the financial statements. The research of Cunha et al. (2017) confirms the existence of a certain link between restatements and earnings management for the Brazilian companies listed on the BM\&FBOVESPA, in the 1995-2012 period. The authors found that in the case of the companies that restated their financial statements, unlike their pairs that did not produce restatements, these events influenced earnings management downwards. The results of this last study are similar to ours, even if the research model was different.

The probability of using creative techniques to influence financial statements is enhanced by the leverage ratio (e.g. Jones \& Sharma, 2001; Shah, 1998). The type of correlation between leverage and earnings management diverges in the results in the literature and can be either positive (e.g. Beatty \& Weber, 2003) or negative (e.g. Jensen, 1986). The other control variables, INVTAN and GOV, do not seem to have significantly influenced the use of earnings management techniques.

\subsection{Robustness tests}

As robustness checks, we first introduced a new variable, Auditor rotation (Auditor_rot in Table 1) and the significance of our main variables (REST and RESTCS) remained the same (see Table 8 ). Also, $\mathrm{R}^{2}$ has about the same value as in the first regression $\left(R^{2}=0.4824\right.$ and $\mathrm{R}^{2}$ Adj. = 0.4677).

Table 7

\section{Model coefficients ${ }^{\mathrm{a}}$}

\begin{tabular}{|c|c|c|c|c|c|}
\hline \multirow[t]{2}{*}{ Model } & \multicolumn{2}{|c|}{ Unstandardized Coefficients } & \multirow{2}{*}{$\begin{array}{c}\begin{array}{c}\text { Standardized } \\
\text { Coefficients }\end{array} \\
\text { Beta }\end{array}$} & \multirow[t]{2}{*}{$\mathbf{t}$} & \multirow[t]{2}{*}{ p-value } \\
\hline & B & Std. Error & & & \\
\hline (Constant) & 0.177 & 0.087 & & 2.03 & $0.044^{*}$ \\
\hline REST & -0.832 & 0.138 & -1.555 & -6.02 & $0.001^{* * *}$ \\
\hline RESTCS & 0.092 & 0.015 & 1.591 & 6.10 & $0.001^{* * *}$ \\
\hline CS & 0.017 & 0.007 & 0.120 & 2.19 & $0.003^{* *}$ \\
\hline GOV & -0.026 & 0.033 & -0.038 & -0.80 & 0.422 \\
\hline LEV & -0.497 & 0.056 & -0.443 & -8.83 & $0.001^{* * *}$ \\
\hline INVTAN & 0.005 & 0.038 & 0.006 & 0.14 & 0.891 \\
\hline
\end{tabular}

Note. a. Dependent Variable: DAC; b. ${ }^{* *} \mathrm{p}<0.01,{ }^{* *} \mathrm{p}<0.05,{ }^{\star} \mathrm{p}<0.1$. 
A model to assess the relationship between management opportunism and auditor reactions. Simulation on financial restatements for a sample of Brazilian companies listed on the NYSE

Table 8

Model coefficients ${ }^{\mathrm{a}}$ - with a supplementary variable, AUDIT_rot

\begin{tabular}{|c|c|c|c|c|c|}
\hline \multirow[t]{2}{*}{ Model } & \multicolumn{2}{|c|}{ Unstandardized Coefficients } & \multirow{2}{*}{$\begin{array}{c}\begin{array}{c}\text { Standardized } \\
\text { Coefficients }\end{array} \\
\text { Beta } \\
\end{array}$} & \multirow[t]{2}{*}{$\mathbf{t}$} & \multirow[t]{2}{*}{ p-value } \\
\hline & B & Std. Error & & & \\
\hline (Constant) & 0.181 & 0.088 & & 2.05 & $0.041^{*}$ \\
\hline REST & -0.812 & 0.140 & -1.518 & -5.82 & $0.001^{* * *}$ \\
\hline RESTCS & 0.090 & 0.015 & 1.551 & 5.87 & $0.001^{* * *}$ \\
\hline CS & 0.017 & 0.008 & 0.122 & 2.21 & $0.028^{* *}$ \\
\hline GOV & -0.027 & 0.033 & -0.039 & -0.81 & 0.416 \\
\hline LEV & -0.497 & 0.056 & -0.444 & -8.81 & $0.001^{* * *}$ \\
\hline INVTAN & 0.005 & 0.039 & 0.006 & 0.12 & 0.891 \\
\hline AUDIT_rot & -0.034 & 0.029 & -0.053 & -1.15 & 0.250 \\
\hline
\end{tabular}

Note. a. Dependent Variable: DAC; b. ${ }^{* *} \mathrm{p}<0.01,{ }^{* *} \mathrm{p}<0.05,{ }^{\star} \mathrm{p}<0.1$.

Table 9

\section{Random Effects model}

\begin{tabular}{ccccc}
\hline \multirow{2}{*}{ Model } & \multicolumn{2}{c}{ Unstandardized Coefficients } & tz & p-value \\
\cline { 2 - 5 } & B & Std. Error & 0.094 & 1.82 \\
0.068 \\
(Constant) & 0.173 & 0.118 & -7.73 & $0.001^{* * *}$ \\
REST & -0.912 & 0.130 & 7.69 & $0.001^{* * *}$ \\
RESTCS & 0.100 & 0.009 & 1.93 & $0.054^{*}$ \\
CS & 0.017 & 0.029 & -0.28 & 0.779 \\
GOV & -0.008 & 0.059 & -8.56 & $0.001^{* * *}$ \\
LEV & -0.507 & 0.033 & 0.980 & 0.329 \\
INVTAN & 0.032 & 0.024 & -0.77 & 0.442 \\
AUDIT_rot & -0.019 & & \\
\hline
\end{tabular}

Note. a. Dependent Variable: DAC; b. ${ }^{* * *} \mathrm{p}<0.01,{ }^{* *} \mathrm{p}<0.05,{ }^{*} \mathrm{p}<0.1$.

As a robustness test we also ran a random effects model on the same data and the results proved to be robust (Table 9), as we obtained the same significant results, for example $\mathrm{R}^{2}=0.4797$. We applied the random effects model believing that the differences between companies, which we could not fully incorporate into the model, have an influence on the dependent variable.

\section{Conclusions}

Bearing in mind the need to enhance financial reporting quality, which leads to benefits for financial information users, we conceived a model to check whether restatements could reduce audit risks (related to estimations and other accounting professional judgements) by decreasing management bias in the subsequent period.

The contributions of our research, which is mainly empirical, can be added to the existing literature on earnings management, audit risks, and restatements. Our study highlights the effects of earnings management practices and management opportunism in general on the quality of financial reporting and hence on the market and users of accounting information, and, last but not least, on the work of auditors (audit risks).

First, we detected earnings management practices in a specific/emerging market context, namely in Brazilian companies listed in the US market, thus responding to our first research question (1). We therefore contribute to the international debate on the subject (e.g. Goncharov et al., 2013; Leippold \& Lohre, 2012; Li et al. 2011; Mehdi, 2011), considering that evidence of accruals anomalies in the US capital market for companies located in an emerging market context is scarce. This confirmation of the existence of earnings management is based on a new version of the discretionary accruals model that we created, based on other models (Vander Bauwhede et al., 2003) and the choice of the variables (Cassel et al., 2014; Chen et al., 2014; Marques et al., 2017; Tan \& Young, 2014) presented in the literature. Hence, we advanced the findings of this group of literature, i.e. on the discretionary accruals model as a measure of earning management. 
Second, the initial result is enhanced by the negative correlation we found between the financial restatements (usually) requested by auditors and discretionary accruals, in the case of accounting estimates, re-classifications, capitalizations/decapitalizations, and other accounting options and policies. These are elements to which the auditor should pay attention when testing management assumptions (especially those relating to earnings management). The connection between restatements and audit quality is confirmed by some other studies (e.g. DeFond, 2010; DeFond \& Zhang, 2014). We found that restatements required by the auditors for one year lead to a decrease in manager opportunistic behavior in the following year. Therefore, our second research hypothesis (2) is confirmed, in line with the findings of previous studies. For the companies listed in the US market, Ettredge et al. (2010) found evidence of increasing use of earnings management prior to restatements, and Elshafie and Nyadroh (2014) observed a positive association between discretionary accruals and audit quality measured by the likelihood of restatements of the financial statements (they used the inverse of the causal relationship in our model). Cunha et al. (2017) confirmed the existence of a link between restatements and earnings management for the Brazilian companies listed on the BM\&FBOVESPA.

Third, our study confirms some of the previous findings in general and for the Brazilian context in particular, regarding the relationship between earnings management and other independent variables besides restatements. Of the four control variables we used in our model, company size and leverage proved to have a statistically significant impact over the likelihood of earnings management, in the sense of intensifying the application of these practices. This is in line with Watts and Zimmerman (1990) and Myers et al. (2003) in terms of the effect of company size on discretionary accruals and with Jones and Sharma (2001) in terms of the probability of the company resorting to earnings management practices when leverage is high. In our study, the leverage ratio could be viewed as a red flag for auditors in their auditing processes, for detecting management bias and to minimize audit risk. In this way, we responded to the invitation made in the literature to provide useful indicators that could warn auditors of the audit risks induced especially by accounting estimates (Christensen et al., 2012; Griffin, 2014). Our study reveals financial restatements as a factor of decreasing management discretion in subsequent periods and leverage as a red flag for this potential behavior.
However, the results of this research should be interpreted in light of a number of limitations. One possible limitation is the exploratory nature of the study, i.e. it examines the relationship between discretionary accruals and restatements, the first being the dependent variable. Other researchers could select different indicators for control variables, for example. Finally, it is also possible that the model we proposed does not sufficiently isolate other influencing factors. These limitations could be countered in future research by conducting a comparative study on companies from several countries, as well as including other variables in the econometric model.

\section{References}

Abernathy, J., Hackenbrack, K. E., Joe, J. R., Pevzner, M., $\&$ Wu, Y. J. (2015). Comments of the auditing standards committee of the auditing section of the American accounting association on PCAOB Staff consultation paper, auditing accounting estimates and fair value measurements: Participating committee members. Current Issues in Auditing, 9(1), C1-C11.

Ardison, K. M. M., Martinez, A. L., \& Galdi, F. C. (2012). The effect of leverage on earnings management in Brazil. Advances in Scientific and Applied Accounting, 5(3), 305-324.

Audit Analytics (AA) (2018). Accounting quality+Risk matrix (AQRM). Retrieved from https://www.auditanalytics. com/doc/aqrmProductManual.pdf

Barron, O., \& Stuerke, P.S. (1998). Dispersion in analysts' earnings forecasts as a measure of uncertainty. Journal of Accounting, Auditing and Finance, 13(3), 245-270.

Beatty, A., \& Weber, J. (2003). The effects of debt contracting on voluntary accounting method changes. The Accounting Review, 78(1), 119-142.

Beckmann, K. S., Escobari, D. A., \& Ngo, T. (2019). The real earnings management of cross-listing firms. Global Finance Journal, 41, 128-145.

Beneish, M.D., Press, E., \& Vargus, M.E. (2012). Insider trading and earnings management in distressed firms, Contemporary Accounting Research, 29(1), 191-220. 
A model to assess the relationship between management opportunism and auditor reactions. Simulation on financial restatements for a sample of Brazilian companies listed on the NYSE

Bratten, B., Gaynor, L. M., McDaniel, L., Montague, N. R., \& Sierra, G. E. (2013). The audit of fair values and other estimates: The effects of underlying environmental, task, and auditor specific factors. Auditing: A Journal of Theory \& Practice, 32, 7-44.

Cassell, C., Myers, J., Myers, L., \& Seidel, T. (2014). Does auditor tenure impact the effectiveness of auditors' response to fraud risk? Retrieved from http://bayanbox. ir/view/4954975882569266661/a154-t36sw.pdf

Chan, K., Jegadeesh, N., \& Sougiannis, T. (2004). The accrual effect on future earnings. Review of Quantitative Finance and Accounting, 22, 97-121.

Chan, K., Chan, L., Jegadeesh, N. \& Lakonishok, J. (2006). Earnings quality and stock returns. Journal of Business, 79(3), 1041-1082.

Chen, K. Y., Elder, R. J., Hung, S. (2014). Do postrestatement firms care about financial credibility? Evidence from the pre-and post-sox eras. Journal of Accounting and Public Policy, 33, 107-126.

Choi, I. 2001. Unit root tests for panel data. Journal of International Money and Finance, 20, 249-227.

Christensen, B. E., Glover, S. M., \& Wood, D. A. (2012). Extreme estimation uncertainty in fair value estimates: Implications for audit assurance, Auditing: A Journal of Practice \& Theory, 31(1), 127-146.

Consoni, S., \& Colauto, R. D. (2016). A divulgação voluntária no contexto da convergência às normas internacionais de contabilidade no Brasil. Revista Brasileira de Gestão de Negócios, 18(62), 658-677.

Cunha, P. R., Fernandes, L. B., \& Dal Magro, C. B. (2017). Influencia do refazimento das demonstraçóes contábeis no gerenciamento de resultados das empresas listadas na BM\&FBOVESPA. RACE: Revista de Administração, Contabilidade e Economia, 16(1), 95-120.

Dechow, P., Ge W., \& Schrand, C. (2010). Understanding earnings quality: A review of the proxies, their determinants, and their consequences. Journal of Accounting and Economics, 50(2-3), 344-401.
Dechow, P., Sloan, R. G., \& Sweeney, A. P. (1995). Detecting earnings management. The Accounting Review, 70(2), 193-225.

Dechow, P. M., \& Dichev, I. D. (2002). The quality of accrual and earnings: The role of accrual estimation errors. The Accounting Review, 77, 35-59.

DeFond, M. L. (2010). Earnings quality research: Advances, challenges and future research. Journal of Accounting and Economics, 50(2-3), 402-409.

DeFond, M. L., \& Zhang, J. (2014). A review of archival auditing research. Journal of Accounting and Economics, 58, 275-326.

Demsey, S. J. (1989). Predisclosure information search incentives, analyst following and earnings announcement price response. Accounting Revue, 64(4), 748-757.

Dichev, I. D., \& Skinner, D. J. (2002). Large-sample evidence on the debt covenant hypothesis, Journal of Accounting Research, 40(4), 1091-1123.

Elshafie, E., \& Nyadroh, E. (2014). Are discretionary accruals a good measure of audit quality? Journal of Management Policy \& Practice, 15(2), 44-59.

Ettredge, M., Scholz, S., Smith, K. R., \& Sun, L. (2010). How do restatements begin? Evidence of earnings management preceding restated financial reports. Journal of Business Finance \& Accounting, 37(3-4), 332-355.

Fang, L., Pittman, J., Zhang, Y., \& Zhao, Y. (2018). Accounting standard precision, corporate governance, and accounting restatements. SSRN Electronic Journal. Retreived from https://papers.ssrn.com/sol3/papers. cfm?abstract_id $=3125008$

Feldmann, H. (2010). Venture capital availability and labor market performance in industrial countries: Evidence based on survey data, KYKLOS, 63(1), 23-54.

Filip, A., \& Raffournier, B. (2014). Financial crisis and earnings management: The European evidence. The International Journal of Accounting, 49(4), 455-478.

Filip, A., Huang, Z., \& Lui, D. (2016). Cross-jurisdictional enforcement difficulty and financial reporting quality. Annual Congress of the European Accounting Association 
(EAA), Maastricht, Netherlands, 39. Retrieved from http://eaa2016.eaacongress.org/r/abstracts

Glover, S. M., Taylor, M., \& Wu, Y. (2014). The gap between auditing experts' performance and regulatory expectations when auditing complex estimates and fair value measurement: Causes and potential solutions. SSRN Electronic Journal. Retrieved from http://ssrn. com/abstract $1 / 42504521 /$

Goncharov, I., Hodgson, A., Lhaopadchan, S. \& Sanabria, S. (2013). Asymmetric trading by insiders-comparing abnormal returns and earnings prediction in Spain and Australia. Accounting and Finance, 53, 163-184.

Griffin, J. B. (2014). The effects of uncertainty and disclosure on auditors' fair value materiality decisions. Journal of Accounting Research, 52(5), 65-93.

Hirschey, M., Smith, K. R., \& Wilson, W. M. (2010). Financial reporting credibility after sox: Evidence from earnings restatements. SSRN Electronic Journal. Retrieved from http://dxdoiorg/102139/ssrn1652982

International Accounting Standards Board - IASB (2012). Conceptual framework for the financial reporting, Retrieved from https://www.ifrs.org/-/media/project/conceptual-framework/ fact-sheet-project-summary-and-feedback-statement/ conceptual-framework-project-summary.pdf?la=en\&hash= 654CC1DE384D992926C9DC50FD2AF49C18A489C6

International Federation of Accountants (IFAC) (2015). International Standard on Auditing (ISA) 700 (Revised), Forming an Opinion and Reporting on Financial Statements. Retrieved from https://www.ifac.org/publications-resources/ international-standard-auditing-isa-700-revised-formingopinion-and-reporting

Jensen, M. C. (1986). Agency costs of free cash flow, corporate finance and takeovers. American Economics Review, 76(2), 323-329.

Jones, J. (1991). Earnings management during import relief investigations. Journal of Accounting Research, 29, $193-228$.

Jones, S., \& Sharma, R. (2001). The impact of free cash flow, financial leverage and accounting regulation on earnings management in Australia's old and new economics. Managerial Finance, 27(12), 18-39.

Kothari, S., Sabino, S., \& Zach, S. (2005). Implications of survival and data trimming for tests of market efficiency. Journal of Accounting and Economics, 39, 129-161.

Larcker, D., \& Richardson, S. (2004). Fees paid to audit firms, accrual choices, and corporate governance. Journal of Accounting Research, 42(3), 625-658.

Leippold, M., \& Lohre, H. (2012). Data snooping and the global accrual anomaly. Applied Financial Economics, 22(7), 509-535.

Lee, G., \& Masulis, R. W. (2009). Seasoned equity offerings: Quality of accounting information and expected flotation costs. Journal of Financial Economics, 92, 443-469.

Li, Y, Niu J., Zhang, R., \& Largay, J. (2011). Earnings management and the accrual anomaly: Evidence from China. Journal of International Financial Management and Accounting, 22, 205-245.

Lillrank, P. (2003). The quality of information. International Journal of Quality and Reliability Management, 20(6), 691-703.

Marques, V. A., Sousa, A. A., Amaral, H. F., \& Santos, K. L. (2017). Determinants of republications in the Brazilian market: An analysis based on earnings management incentives. Journal of Education and Research in Accounting, 11(2), 191-213.

Mehdi, I. (2011). An examination of the naïve-investor hypothesis in accruals mispricing in Tunisian firms. Journal of International Financial Management and Accounting, 22(2), 131-164.

Myers, J. N., Myers L. A., \& Omer, T. C. (2003). Exploring the term of the auditor-client relationship and the quality of earnings: A case for mandatory auditor rotation? The Accounting Review, 78(3), 779-799.

Muresan, D. (2014). Accruals anomaly: A survey of the methods used to measure accruals. Conference of ASECU: Towards post-crisis prosperity: Alternative Economic Policies and Institutional Reforms in Southern and Eastern Europe, Risoprint, Cluj-Napoca, Romania, 10. Retrieved from http://www.asecu.gr/files/10th_conf_files/muresan.pdf 
A model to assess the relationship between management opportunism and auditor reactions. Simulation on financial restatements for a sample of Brazilian companies listed on the NYSE

Mureșan, D., \& Pop Silaghi, M. I. (2014). Empirical evidence on cross-country differences in explaining accruals anomaly. Romanian Journal of Economics, 48(2), 121-132.

Nobes, C., \& Parker, R. (2006). Comparative International Accounting. London: Prentice Hall.

Pincus, M., Rajgopal, S., \& Venkatachalam, M., (2007). The accrual anomaly: International evidence. The Accounting Review, 82(1), 169-203.

Prather-Kinsey, J., \& Waller Shelton, S. (2005). IAS versus US GAAP: Assessing the quality of financial reporting in South Africa, The United Kingdom, and the United States, Advances in International Accounting, 18,153-168.

Public Company Accounting Oversight Board - PCAOB (2011, Dec.).Assessing and Responding to Risk in the Current Economic Environment, Staff Audit Practice Alert No. 9. Retrieved from https://pcaobus.org/Standards/ QandA/12-06-2011_SAPA_9.pdf

Public Company Accounting Oversight Board - PCAOB (2014). Auditing Accounting Estimates and Fair Value Measurement. Staff Consultation Paper: August 19. Washington, DC: PCAOB . Retrieved from https:// pcaobus.org/Standards/Documents/SCP_Auditing Accounting_Estimates_Fair_Value_Measurements.pdf

Reynolds, J. K., \& Francis, J. R. (2000). Does size matter? The influence of large clients on office-level auditor reporting decisions. Journal of accounting and economics, 30(3), 375-400.

Shah, A.K. (1998).Exploring the influences and constraints on creative accounting in the United Kingdom. The European Accounting Review, 7(1), 83-104.

Srinidhi, B., \& Gul, F. (2007). The differential effects of auditors' non-audit and audit fees on accrual quality. Contemporary Accounting Research, 24, 595-629.

Sloan, R. (1996). Do stock prices fully reflect information in accruals and cash flows about future earnings? Accounting Review, 71(3), 289-315.
Tan, C. E. L., \& Young, S. M. (2014). An analysis of 'little r' restatements. Fordham University Schools of Business Research (Paper No. 2407659). http://dx.doi. org/10.2139/ssrn.2407659

Tan, C. E. L., \& Young S. M. (2015). An analysis of "little r" restatements. Accounting Horizons, 29(3), 667-693. https://doi.org/10.2308/acch-51104

Tejedo-Romero, F., Araujo, J. F. F. E., \& Emmendoerfer, M. L. (2017). Corporate governance mechanisms and intellectual capital. Revista Brasileira de Gestâo de Negócios, 19(65), 394-414.

Tsipouridou, M., \& Spathis, C. (2014). Audit opinion and earnings management: Evidence from Greece, Accounting Forum, 38(1), 38-54.

Sievers, S., \& Sofilkanitsch, C. (2018, august). Financial restatements: Trends, reasons for occurrence, and consequences - a survey of the literature. Taxation, Accounting, and Finance (TAF Working paper, No. 35). Retrieved from https://wiwi.uni-paderborn.de/fileadmin/ cetar/TAF_Working_Paper_Series/TAF_WP_035_ SieversSofilkanitsch_2018.pdf

Staubus, G. J. (2000). The decision-usefulness theory of accounting: A limited history (New works in accounting history). New York: Garland Publishing.

Vander Bauwhede, H., Willekens, M., \& Gaeremynck, A. (2003). Audit firm size, public ownership and firms' discretionary accruals management. The International Journal of Accounting, 38, 1-22.

Xie, H. (2001). The mispricing of abnormal accruals. The Accounting Review, 76(3), 357-373.

Zang, A. (2012). Evidence on the trade-off between real activities manipulation and accrual-based earnings management. The Accounting Review, 87(2), 675-703.

Watts, R. L., \& Zimmerman, J. L. (1990). Positive accounting theory: A ten year perspective. Accounting Review, 131-156. 


\section{Financial support:}

This paper was supported by a mobility grant from the Romanian Ministry of Research and Innovation, CNCS - UEFISCDI, project number PN-III-P1-1.1-MC-2017-2468, within PNCDI III.

\section{Copyrights:}

RBGN owns the copyrights of this published content

\section{Plagiarism analysis}

RBGN performs plagiarism analysis on all its articles at the time of submission and after approval of the manuscript using the iThenticate tool.

\section{Authors:}

1. Adela Deaconu, PhD. in Accounting, Babes-Bolyai University, Cluj-Napoca, Romania.

E-mail: adela.deaconu@econ.ubbcluj.ro

2. Camelia-Daniela Hategan, PhD. in Accounting, West University of Timisoara, Timisoara, Romania.

E-mail: camelia.hategan@e-uvt.ro

3. Ioana Ciurdas, PhD. Student in Accounting, Babes-Bolyai University, Cluj-Napoca, Romania.

E-mail: ioana.ciurdas@econ.ubbcluj.ro

\section{Authors' Contributions}

Adela Deaconu: Definition of research problem; Development of hypotheses or research questions (empirical studies); Development of theoretical propositions (theoretical work); Theoretical foundation/literature review; Definition of methodological procedures; Analysis and interpretation of data; Critical revision of the manuscript; Manuscript writing. Camelia-Daniela Hategan: Development of theoretical propositions (theoretical work); Theoretical foundation / Literature review; Data collection; Manuscript writing.

Ioana Ciurdas: Theoretical foundation / Literature review; Data collection; Statistical analysis; Manuscript writing. 